\title{
THIRD CENTURY ISLAMIC ECONOMIC THOUGHTS YAHYA BIN UMAR AND AHMAD BIN HANBAL III H / 9 M
}

Elvina Rahmi, ${ }^{1}$ Ridho Nur, ${ }^{2}$ Elfia, ${ }^{3}$ and Merison $^{4}$

${ }^{1}$ UIN Imam Bonjol Padang, Padang, elvinarahmi60@gmail.com

${ }^{2}$ UIN Imam Bonjol Padang, Padang, ridhonur@gmail.com

${ }^{3}$ UIN Imam Bonjol Padang, Padang, elfiamag@uinib.ac.id

${ }^{4}$ UIN Imam Bonjol Padang, Padang, Meirison.a@gmail.com

\begin{abstract}
This article discusses the history of economic thought in the third century. Islam has provided all the guidelines or guidelines for humans to live in the world, both morally and economically. One of the most important economic activities that Islam promotes is the Qur'anic trade, and the hadith explains much about the profession. Where business is essential for the survival of humankind as civilization progresses on the surface of the earth, especially in the field of commerce where every trader competes for profit. Unfortunately, as the civilization of the traders begins to do everything to profit without regard to the rules laid down in the Sharia, one of the ways traders can benefit from unhealthy habits is to practice Siyasah al-Ighraq (dumping). And the people who talk about this are Yahya Bin Umar and Ahmad Bin Hanbal. The method in this study is library research aimed at studying the concept of a legal matter, using descriptive-analytical methods, normative-economic, and sociological approaches. The results show that the focus of Yahya bin Umar's attention is on the market rules that are reflected in the discussion of the bag (pricing). Implementation of prices (al-tas'ir) is a dominant theme in the book of Ahkam al-Suq, the author of the book, Imam Yahya bin Umar, repeatedly discussing it in various places. Apparently, he wants to say that price existence is an essential thing in a transaction and neglecting it can cause damage to people's lives. Related to this. Yahya bin Umar argues that al-tas'ir (pricing) cannot be done. Likewise, with Imam Ahmad, he criticized buyers who bought other people's goods at the same time. A seller who loses his price will monopolize the commodity, and if there is no competition, he can give it whatever he wants. Be more careful when making decisions. Imam Ahmad requested that such cases be remedied to avoid monopoly and other unpleasant practices.
\end{abstract}

Keywords: Yahya Bin Umar, Ahmad Bin Hanbal, Economics

Abstrak. Artikel ini membahas tentang sejarah pemikiran ekonomi Islam abad ke III. Islam telah memberikan semua petunjuk atau pedoman kepada manusia untuk hidup di dunia baik dalam hal akhlak, maupun ekonomi. Salah satu kegiatan ekonomi yang sangat di anjurkan oleh Islam adalah perdagangan Al-Quran dan hadis banyak 
menjelaskan tentang perdagangan, dimana perdagangan sangat penting untuk kelangsungan hidup umat manusia. Seiring berjalannya waktu kemajuan peradaban di muka bumi semakin pesat terutama dalam bidang perdagangan dimana setiap pedagang berlomba-lomba untuk mencari keuntungan, sayangnya seiring majunya peradaban para pedagang mulai melakukan segala hal untuk mendapatkan keuntungan tanpa mementingkan lagi aturan-aturan yang telah di atur dalam syariat, salah satu cara yang dilakukan para pedagang untuk memperoleh keuntungan dengan cara yang tidak sehat adalah melakukan praktik Siyasah al-Ighraq (dumping). Adapun tokoh yang membahas tentang ini yaitu Yahya Bin Umar dan Ahmad Bin Hanbal. Metode dalam penelitian ini yaitu penelitian kepustakaan (library research) ini bertujuan untuk mengkaji konsep hukum benda, dengan menggunakan metode deskriptif-analitis, pendekatan normatif-ekonomi dan sosiologi. Hasil penelitian menunjukkan Fokus perhatian Yahya bin Umar terfokus pada hukum-hukum pasar yang terefleksikan dalam pembahasan tentang tas'ir (penetapan harga). Penerapan harga (al-tas'ir) merupakan tema sentral dalam kitab Ahkam al- Suq penyusun buku tersebut, Imam Yahya bin Umar, berulang kali membahas nya di berbagai tempat yang berbeda. Tampaknya, ia ingin menyatakan bahwa eksistensi harga merupakan hal yang sangat penting dalam sebuah transaksi dan pengabaian terhadapnya kan dapat menimbulkan kerusakan dalam kehidupan masyarakat. Berkaitan dengan hal ini. Yahya bin Umar berpendapat bahwa al-tas'ir (penetapan harga) tidak boleh dilakukan. Begitu juga dengan Imam Ahmad, ia mencela pembeli yang membeli barang orang lain yang dibeli sekaligus. Seorang penjual yang kehilangan harga akan memonopoli komoditi tersebut dan jika bersaing sudah tidak ada, dia bisa memberikan harga sesukanya. Harus lebih berhatihati dalam mengambil keputusan. Imam Ahmad meminta agar masalah hukum-kasus demikian untuk menghindari monopoli dan praktik yang tidak menyenangkan lainnya.

Kata Kunci: Yahya Bin Umar, Ahmad Bin Hanbal, Ekonomi

\section{Preliminary}

Muslim contributions to the survival and development of the economy in particular and world civilization in general have been ignored by western scientists. Even textbooks of Western economies almost never mention the role of the Muslims, even though so most of the fault lies in the hands of the Muslims for not actualize adequate contribution of Muslims, so that the west has a big hand in this case because it does not give a proper appreciation 
of the contributions of other civilizations for the advancement of human knowledge. ${ }^{1}$

However, in the middle of the 9th century AD was the century in which the Islamic world was experiencing a golden age (Golden Age). ${ }^{2}$ Science is making significant progress. The progress of science is marked by the emergence of educational institutions and the birth of large scholars. Even some madhab of thought, especially ahl al-ra'y and ahl al-hadith have begun to emerge and develop. The Hanafi madhab of thought that is ahl al-ra'y has developed in Kufa and the Maliki madhab which is ahl al-hadith has developed in Medina. ${ }^{3}$ At the same time, country's economy and society have demonstrated development and progress. The development of economic activities was in line with the progress and glory of the Abbasid Dynasty as the ruler at that time. Economic activity has developed in various sectors such as; agriculture, plantation, trade and industrial sectors. ${ }^{4}$

Yahya bin Umar and Ahmad Bin Hanbal, as one of the great scholars of their time, were born when science and economics were progressing. This paper aims to express the concept of economic thought and market policy from Yahya bin Umar.

From the discussion above, the author wants to convey a number of core issues, including:

1. History of Islamic Economic Thought Yahya Bin Umar

2. History of Islamic Economics Thought Ahmad Bin Hanbal

The research method using library research. This method aims to examine the concept of the law of objects, using descriptive-analytical methods, normative-economic approaches and sociology. While the novelty of this paper is the theoretical implications of the thoughts of Yahya bin Umar and Ahmad bin Hanbal on the economic thought of Sharia and the benefit of the Muslims.

History of Islamic Economic Thought Yahya Bin Umar

Biography of Yahya Bin Umar

Yahya bin Umar is one of the Maliki madhab fuqaha. The cleric whose full name is Abu Bakar Yahya bin Umar ibn Yusuf Al-Kananni Al-Andalusi was born in

\footnotetext{
${ }^{1}$ M.Umer Chapra, Islam and Economic Challenges (Gema Insani Press, 2000), 261.

${ }^{2}$ Hugh Kennedy, The Prophet and the Age of the Caliphates: The Islamic Near East from the Sixth to the Eleventh Century, 2. ed., A history of the Near East (Harlow: Pearson Longman, 2004), 115.

${ }^{3} \mathrm{Abu}$ Yasid, Islam akomodatif: rekonstruksi pemahaman Islam sebagai agama universal, Cet. 1. (Yogyakarta: LKiS, 2004), 60.

${ }^{4}$ Dr. Yadi Janwari M.A Dr.Yadi Janwari M.A, Pemikiran Ekonomi Islam dari Masa Rasulullah Hingga Masa Kontemporer (Jakarta: PT Remaja Rosdakarya., 2016), 144. 
$213 \mathrm{H}$ and raised in Cordova, Spain. Like previous Muslim scholars, he travelled to various countries to study. At first, he stopped in Egypt and learned from the leaders of Sahabah of Abdullah bin Wahab Al-Maliki and Ibn Al-Qasim, like Ibn AlKirwan Ramh and Abu Al-Zhahir bin Al-sharh after that, he moved to Hijaz and studied, among them, to Abu Mus'ab Az-Zuhri. Finally, Yahya bin Umar settled in Qairuwan, Africa, and perfected his education with a faraid (Knowledge of inheritance law) expert and reckoning, Abu Zakaria Yahya bin Sulaiman AlFarisi. In further developments, he became a teacher at Jami 'al-Qairuwan. During his lifetime, there was a sharp conflict between the Malikiyah fuqaha and the Hanafiyah fuqaha triggered by competition for influence in government. ${ }^{5}$ Yahya bin Umar was forced to leave Qoiruwan and settled in Sausah when Ibn 'Abdun, who tried to get rid of his opposing Ulama, either by imprisonment or by killing, served as a qadi in the country. After Ibn 'Abdun stepped down from his post, Ibrahim bin Ahmad Al-Aglabi offered the position of qadi to Yahya bin Umar. However, he refused and chose to remain in Sausah and teach at Jami 'AlSabt until the end of his life. Yahya bin Umar died in 289 H (901 AD).

\section{The works of Yahya Bin Umar}

During his life, besides actively teaching, Yahya bin Umar also produced many papers up to 40 juz. ${ }^{6}$ Among his famous works are the book of al-Mutakhabah fi Ikhtisaral-Mukstakhrijah fi al_Fiqh al-Maliki and the book of Ahkam al-Suq. The book Ahkam al-Suq originating from the continent of Africa in the third century of the Hijriyah is the first book in the Islamic world that is specifically discussed about hisbah and various laws of the market, one of the things that influence it is the condition of Qairuwan, where Yahya bin Umar spent the most important part of his life.

At that time, the city had a permanent market institution since $155 \mathrm{H}$ and its rulers, from the time of Yazid bin Hatim Al-Muhibli until before the time of Ja'far Al-Manshur, were very concerned about the existence of market institutions. In fact, in $234 \mathrm{H}$, Kanun, the ruler of the city judiciary, appointed a qadi (judge) who specialized in dealing with market issues. Thus, at the time of Yahya bin Umar, the city of Qairuwan already had two features:

The existence of market institutions receives special attention and adequate regulation from the authorities. In the judiciary, there is a judge who specializes in dealing with market issues.

\footnotetext{
${ }^{5}$ Adiwarman Azwar Karim, Sejarah pemikiran ekonomi Islam, Ed. 3. (Jakarta: PT RajaGrafindo Persada, 2006), 118. ${ }^{6}$ Ibid., 119. 
About the book Ahkam al-Suq Yahya ibn Umar said that the writing of this book was created due to two fundamental issues, namely first Islamic Sharia on the scales and dosing unity differences goods among regions. The second Sharia law about uncontrolled wheat prices due to the implementation of price liberalization is feared to cause harm to consumers. By doing so, Ahkam al-Suq actually an explanation of the answer to both issues.

In discussing both of these issues, Yahya ibn Umar explained in a comprehensive accompanied by a lengthy discussion to go beyond the answers needed before answering he wrote the preamble in detail about the various responsibilities conduct market inspection, control scales and dosage, as well as revealing about the currency. When viewed from the side of the method of discussion this means that the discussion in the Ahkam alSuquses more discussion or dialogue methods than the percentage categorization method. Yahya bin Umar is believed to have taught the book for the first time in the city of Sausah in the post-conflict period. In subsequent developments, there is a history of this book, the history of al-Qashri which we now study and the history of al-Shibli.

\section{Economic Thought of Yahya Bin Umar}

According to Yahya bin Umar economic activity is an inseparable part of a Muslim's submission to Allah. This means that piety is a principle in the Islamic economy. As well as the main factors that distinguish Islamic economics from conventional economics. Therefore, besides the Koran, every Muslim must hold tightly to the sunnah and follow all the commands of the Prophet Muhammad Saw., in carrying out every economic activity.

As mentioned, the focus of Yahya bin Umar's focus is on market laws that are reflected in the discussion on tas'ir (price fixing). The application of price (altas'ir) is a central theme in the book Ahkam al-Suq the compiler of the book, Imam Yahya bin Umar, repeatedly discussing it in various different places. Apparently, he wanted to state that the existence of a price is very important in a transaction and neglect of it can cause damage to people's lives.

Related to this matter. Yahya bin Umar argues that al-tas'ir (price fixing) cannot be done. He worshiped with various traditions of the Prophet Muhammad from Anas bin Malik, he said: "has jumped prices (in the market) during the time of Rasulullah S. They (Sahabah) said:" O Messenger of Allah, set a price for us ". The Messenger of Allah answered: "Indeed, Allah is the one who controls (the price), who gives sustenance, who makes it easy, and who sets the price. I really hope 
to meet Allah and no one (may) ask me to commit an injustice in matters of soul and wealth" (Riwayah Abu Dawud).?

If we examine the context of the hadith, it seems clear that Yahya bin Umar prohibited the pricing policy (tas'ir) if the price increase that occurred was merely a natural result. In other words, in such a case, the government does not have the right to intervene in prices. This will be different if the price increase caused by human activity (human error).

The government, as a formal institution that bears the responsibility of creating public welfare, has the right to intervene in prices when an activity occurs that can endanger the lives of the wider community. Yahya bin Umar stated that the government must not intervene except in two cases, namely: ${ }^{8}$

a. The traders do not trade certain goods that is needed by the community, so that it can cause harm and damage the mechanism. In this case, the government can get the traders out of the market and replace them with other traders, based on public benefit and maslahah.

b. Traders practice Siyasah al-Ighraq or dumping prices which can cause unfair competition and can disrupt market price stability. In this case, the government has the right to order the traders to raise their goods back in accordance with the prices prevailing in the market. If they reject it, the government has the right to expel the traders from the market. This was once practiced by Umar bin Al-Khattab when he got a raisin trader selling his goods below the market price. He gives the trader the choice, whether to raise the standard price prevailing in the market or different from the market. ${ }^{9}$

Yahya ibn Umar's statement clearly indicates that the law of government intervention is haram. New interventions can be carried out if and only if the welfare of the general public is threatened. This is in accordance with the duties assigned to the government in realizing social justice in every aspect of community life, including the economy. In addition, his opinion which prohibits the practice of tas'ir (price fixing) at the same time shows that in fact Yahya bin Umar supports economic freedom, including freedom of ownership. ${ }^{10}$

The attitude of the Prophet Saw., refusing to set prices is also an early indication that in the Islamic economy it is not only limited to regulating special

سنن أبي داود (بيروت، لبنان : دار المعرفة, ,et al. 272 ,2001.

${ }^{8}$ Meirison Meirison, "Riba and Justification in Practice in Scholars' Views," TRANSFORMATIF 2, no. 1 (September 20, 2018): 348.

${ }^{9}$ Karim, Sejarah pemikiran ekonomi Islam, 287.

${ }^{10}$ Meirison Alizar Sali, "Distinction of Justice and Fairness during Umar Bin Abdul Aziz's Reign," AJIS: Academic Journal of Islamic Studies 4, no. 2 (December 9, 2019): 127. 
ownership, but also respecting and protecting it. Of course, the intended economic freedom is not absolute freedom as is known in conventional economics, but freedom which is bound by Islamic law.

The market is the centre of the supply and demand of goods. Market position in Islam is so high, because in addition to agriculture and trader as professions that are highly recommended by Islam. The characteristic of the Islamic market is that there are rules, mechanisms and values of Islam which are used as standard activities. This characteristic is the uniqueness of Islam that does not recognize the dichotomy of the world and the hereafter. Materially oriented business activities are always balanced with a love of spending wealth in the path of Allah (spiritual). Islam is a religion that upholds freedom in economics. So that Islam gives freedom to his people to innovate and creativity in muamalah (social life). ${ }^{11}$

Under these conditions, the government is prohibited from intervening in prices. In Article 5 paragraphs 1 and 2 of Law No. 5 of 1999 indicates a prohibition on conspiracy in order to set prices in the market. Speaking of price regulation, we certainly remember that price controls first appeared in the time of the Prophet Muhammad. At that time the Prophet acted as Hasib (supervisor). At that time, the community was faced with a condition of high prices, so sahabah asked the Apostle to reduce prices. However, the Apostle refused the sahabah's request. The Apostle said: "Allah acknowledges the advantages and disadvantages, He is the maker of prices that changes and becomes the true price, I pray that the prohibition of doing economic activity in the market, is not in the form of maliyah punishment.

Regarding ihtikar, Yahya bin Umar stated that the emergence of harm to society was a condition for the prohibition of stockpiling. If that happens, the goods from the stockpile must be sold and the profits from the sale are provided as education for the ihtikar practitioners.

The ihtikar actors themselves are only entitled to get their principal capital. Furthermore, the government warns the ihtikar perpetrators not to repeat their actions. If they do not heed the warning, the government has the right to punish them by beating, surrounding the city, and imprisoning them. Thus, in the case of price increases due to human actions, such as ihtikar and dumping, the policy taken by the government is to return the price level to the equilibrium price. This also means that in Islamic economics, the law has a role as a guardian and guarantor of the implementation of community rights that can improve the welfare of their lives as a whole, not as an instrument of power to obtain wealth arbitrarily.

${ }^{11}$ Meirison Meirison, “Mashlahah Dan Penerapannya Dalam Siyasah as Syar'iyah," Ijtihad 32, No. 1, 2019. 
History of Economic Thought Ahmad Bin Hanbal

Biography of Ahmad Bin Hanbal

His full name is Ahmad bin Muhammad bin Hanbal bin Asad bin Idris bin Abdullah bin Hasan As-Syaibany. ${ }^{12}$ Ahmad bin Muhammad ibn Hanbal alSyaibaniy was born in Baghdad precisely in the city of Maru/Merv, the city of his mother's birth, in the month of Rabi'ul Awal $164 \mathrm{H}$ or November $780 \mathrm{AD}$. which is still a descendant with the Prophet Muhammad, in Mazin bin Mu'ad bin 'Adnan. The name Hanbal is actually the name of his grandfather and became his nickname because in order to respect his descendants. He was born in Baghdad in the month of Robiu'l Awal in the year $164 \mathrm{H}^{13}{ }_{-}$The nickname was Abu Abdillah. His grandfather, Hanbal ibn Hilal was the Governor of Sarakhs who along with the Abbasid dynasty actively opposed the Umayyad dynasty in Khurasan. When Ahmad was a child, his father passed away to Rahmatullah by only leaving a mediocre treasure to support his family. Since the death of his father, his mother has not remarried. This was done with the aim that he could focus his attention on Ahmad so that he could grow as he had hoped. His mother was named Safiyyah bint Maimunah bint Abdul Malik as Syaibany. ${ }^{14}$

Ahmad ibn Hanbal grew up in Baghdad and was educated initially in cities that until the age of 19 years. Since childhood, Ahmad has been sent to a Qira'at expert. At a relatively small age he was able to memorize the Koran and also learn Hadith for the first time to Abu Yusuf, a ra'yi expert and one of Abu Hanifah's friends. Abu Yusuf was a Supreme Judge in the Bani Abbasid government. Because of Ahmad's love for the hadith, early in the morning he always went to the mosques until his mother missed him.

The living conditions, which were simple and mediocre from the beginning, became one of the driving forces for Ahmad to study seriously. He has an obsession to immediately reduce the burden on the mother.

Ahmad bin Hanbal memorized the Koran at a relatively young age, he learned hadith, language, and administrative issues. He learned a lot from a number of scholars and great fuqaha, one of whom was Abu Yusuf (d. 182 H), a judge and student of Abu Hanifa. From Abu Yusuf he learned fiqih ahlu ra'yu. After some time studying the fiqih of ahlu ra'yu he turned to the study of the sunnah and hadith which he had originally learned from Hisham bin Basyir ibn Abi Khazim, a

${ }^{12}$ Huzaimah Tahido Yanggo, Pengantar Perbandingan Madzhab (Jakarta: Gaung Persada, 2011), p. 154.

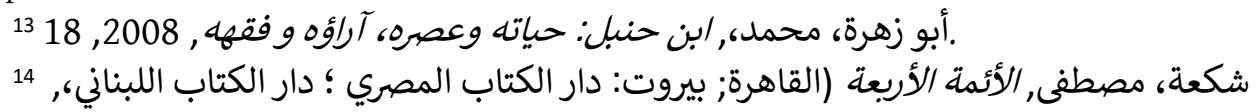


figure of ahlu hadith in Baghdad. For four years he learned the hadith from his teacher by gaining a very broad knowledge of the traditions and writing about 300,000 traditions. Next, he studied the hadith of Imam al-Syafi'i, especially in the field of formulation and legal making techniques.

To deepen his knowledge, he wandered to various regions such as Kufa, Basra, Medina, Makkah and Yemen. In Makkah, Ahmad bin Hanbal studied the science of fiqih and the proposal of fiqih to Imam al-Syafi'i. At the age of 40 years he returned to his hometown with a set of knowledge and has reached the degree of mujtahid because he authoritatively deserves to do ijtihad independently and this is where he came to be known as the Hanbali madhab. ${ }^{15}$ Another source states that one day someone who reprimanded him, Ya Abdullah (nickname of Ahmad bin Hanbal), you have reached the level of mujtahid and you are worthy of being a Muslim imam, whether you will bring the inkwell to the grave, Ahmad replies calmly, I will study until I enter the grave. ${ }^{16}$

On the other side of his life, especially while in Baghdad, Ahmad saw a lot of social inequality and economic inequality. He lived as a commoner, lived in their midst and felt their pain and sorrow. He also saw the number of heresies that was spread in the community. This was precisely what prompted him to go to various regions in search of hadith.

Ahmad has two sons who are famous in the field of hadith namely Salih and Abdullah. His two sons received many hadiths from his father and included a number of hadiths in his father's Musnad. Ahmad a scientist who productive among his work, 'Ilal, al-Tafseer al-Nasikh wal mansukh, Kitab al-zuhd, albahtsul, books fada'ilfada'il shabah book of al-Fara'id, al mansukh, the book of al - Faith, Kitab al-Ashribah, Ta'at Rasul and Kitab al-Ra'ad'ala Jahmiyah. The most glorious and famous book is Musnad Ahmad.

Referring to the description above, it is understood that Ahmad bin Hanbal was very enthusiastic in seeking knowledge and his involvement in various scientific studies in his day placed him as one of the fatwa experts who were highly respected and desirable by Muslims, so he was also known as a figure who loved very much the thoughts of his predecessor, such as Imam al-Shafi'i he even said that only al-Shafi'i was worthy of giving a fatwa in his day. His admiration for al-Shafi'i more or less influenced his way of thinking in conducting ijtihad. This also proves that he has great attention to the issues of Fiqih. ${ }^{17}$

${ }^{15}$ Roibin, Dimensi-Dimensi Sosio-Antropologis Penetapan Hukum Islam Dalam Lintasan Sejarah, Cetakan I. (Malang: UIN-Maliki Press, 2010), p. 81.

${ }^{16}$ Ahmad Kholik Ahmad Kholik, Melacak Sejarah Metodologi Ijtihad (Bandung: Shahifah, 2009), p. 230.

${ }^{17}$ Dedi Ismatullah, Sejarah Sosial Hukum Islam (Bandung: Pustaka Setia, 2011), p. 314. 
The city of Baghdad as a city of science has made Ahmad a famous figure because of his scholarship and his strong attitude to maintain faith. Ahmad Bin Hanbal died on Friday in the month of Rabiul Awal in $241 \mathrm{H}$ (855 AD) in his hometown of Baghdad.

The works of Ahmad Bin Hanbal

While receiving, he busied himself in seeking knowledge, giving fatwas and recording hadiths. The first person from whom he took the hadith was Al-Qadhi Abu Yusuf, pupil/colleague of Imam Abu Hanifa. He took many hadiths and the benefits of knowledge from Imam Shafi'i. Imam Shafi'i himself highly glorified Imam Ahmad and asked for a reference to recognize the validity of a hadith. He compiled his famous book, Al-Musnad, in a period of about sixty years and it had begun since the first time he searched for the hadith. He also compiled books on interpretation, about an-nasikh wa Al-Mansukh, about tarikh, about the Muqoddam wa mu 'akhar in the Qur'an, about the answers in the Qur'an.

The books he compiled are the books of al-Manasik ash-Shagir and al-Kabir, the book of az-Zuhud, the book of ar-Radd 'ala al-Jahmiyah wa az-Zindiqah (Rebuttal to Jahmiyah and Zindiqah), the book as-Shalah, the book as-Sunnah, the book alWara 'wa al-Imam, the book al-Ilal wa ar-Rijal, the book al-Asyribah, one juz about Usul as-Sittah, Fadha'il ash-Shahabah. ${ }^{18}$

\section{Economic Thought of Ahmad Bin Hanbal}

Abu Zahra conveyed Imam Ahmad's views representing Islam in winning fair competition in the market. Imam Ahmad denounces buyers who buy other people's goods that are bought at once. A seller who loses price will monopolize the commodity and if there is no competition, he can give the price at will. Must be more careful in making decisions. Imam Ahmad requested that the case-law matter be to avoid monopolies and other unpleasant practices. ${ }^{19}$

Another thought that gives maximum freedom in contracts and companies. Imam Ahmad allowed terms in contracts that other Islamic law madhab in his time were not permitted. He likes to be free to use the concept of maslaha on problems that have no solution. The method is more attractive for the benefit of the weak and poor.

\footnotetext{
${ }^{18}$ Muammer Gül, “İSLAM İKTISSADİ GELIŞMESININ TARİHI VE DINI DİNAMIKLERİ,” Journal Of History School 7, no. XVII (January 1, 2014): 71-106.

${ }^{19} \mathrm{Fu}$ 'ād 'Abd Allāh 'Umar, Muqaddimah fi tārìkh al-iqtiṣād al-Islāmī wa-tațawwurih (Jiddah: al-Bank al-Islāmī lil-Tanmīyah - al-Ma'had al-Islāmī lil-Buhūth wa-al-Tadrīb, 2003). 
He also interviewed homeowners to provide shelter for those who did not have a reception area.

\section{Conclusion}

During his life, besides actively teaching, Yahya bin Umar also produced many papers up to $40 \mathrm{juz}$. Among his famous works are the book of al-Mutakhabah fi Ikhtisaral-Mukstakhrijah fi al_Fiqh al-Maliki and the book of Ahkam al-Suq. The book Ahkam al-Suq derived from the African continent in the third century Hijriyah. This is the first book in the world of Islam specifically discussed hisbah and various laws of the market, one of the things that influenced it is the situation of the city Qoiruwan, where Yahya ibn Umar spent the most important part of his life.

The yasah al-Ighraq or known as dumping is an act that is prohibited both in the context of positive law and Islamic law, this is because it can cause chaos and inequality in the economy. Lowering prices below prevailing prices on the market can cause a lot of distortion for the economy because of too low prices, there will be excess demand because consumers buy at prices that are cheaper than they should. But for producers this price is clearly unprofitable so it is likely to be reluctant to release its goods to the market. The sellers will tend to sell their goods to other markets (black market) that can give it a higher price. In the modern thought of Yahya bin Umar he also expressly forbids the practice of Siyasah al-Ighraq because of its negative impact on the benefit of the wider community in general and specifically to producers or traders, this can kill other traders selling the same product because with reduce the price of goods below the standard consumers will be more attracted to the same products but at prices that are much cheaper than the market.

Yahya bin Umar's thought about Siyasah al-Ighraq (dumping) with the existing trade law in Indonesia has some relevance including the prohibition of the practice of Siyasah al-Ighraq which explicitly prohibits the practice because it can cause harm to the wider community, specifically to producers who sell the same goods when one trader practices Siyasah al-Ighraq (dumping), then consumers will be interested in buying the same goods at producers who carry out the practice because the price is cheap, on the other hand other producers or traders who not lowering prices or not practicing Siyasah al-Ighraq (dumping) will go bankrupt due to the practice of Siyasah al_Ighraq (dumping).

In this case there are differences in terms of government intervention wherein in the thought of Yahya bin Umar the government is strictly prohibited from intervening or interfering in the market when the market is stable or has no problems, according to Yahya bin Umar the government can Intervene when there is fraud caused by human activity (human error) in this case there are two 
namely ihtikar (monopoly) and Siyasah al-Ighraq (dumping) which are considered to be very bad for the wider community when the practice occurs, the command has the right to interfere when things happen like this.

As for Ahmad Bin Hanbal, Ahmad bin Hanbal was very enthusiastic in seeking knowledge and his involvement in various scientific studies in his day placed him as one of the fatwa experts who were highly respected and sought after by Muslims, so he was also known as a figure who loved thoughts of his predecessor, like Imam al-Shafi'i even said that only al-Shafi'i was worthy of giving a fatwa in his day. His admiration for al-Shafi'i more or less influenced his way of thinking in conducting ijtihad. This also proves that he has a great interest in fiqih issues. ${ }^{20}$

The city of Baghdad as a city of science has made Ahmad a famous figure because of his scholarship and his strong attitude to maintain faith. Ahmad Ibn Hanbal died on Friday of the month of Rabi'ul Awal in 241 H (855 AD) in his hometown of Baghdad. We can know that Ahmad ibn Hanbal was a scientist who included most textual law in understanding the Qur'an and Sunnah. His love for the sunnah and hadith of the Prophet Muhammad, made him known to the wider community as a hadith scientist rather than a fiqih scientist. As a very persistent defender of the Prophet's hadith, it can be seen from the methods used in deciding the law, that is, not using reason except in very forced circumstances.

Imam Ahmad denounces buyers who buy other people's goods that are bought at once. A seller who loses price will monopolize the commodity and if there is no competition, he can give the price at will. Must be more careful in making decisions. Imam Ahmad requested that the case-law matter be to avoid monopolies and other unpleasant practices.

Another thought that gives maximum freedom in contracts and companies. Imam Ahmad allowed terms in contracts that other Islamic law madhab in his time were not permitted. He likes to be free to use the concept of Maslahah on problems that have no solution. The method is more attractive for the benefit of the weak and poor.

The books he compiled are the books of al-Manasik ash-Shagir and al-Kabir, the book of az-Zuhud, the book of ar-Radd 'ala al-Jahmiyah wa az-Zindiqah (Rebuttal to Jahmiyah and Zindiqah), the book of as-Salah, the book of as-Sunnah, the book of al-Wara 'wa al-Iman, the book of al-'Ilal wa ar-Rijal, the book of al-Asyribah, one juz about Usul as-Sittah , Fadha'il ash-Shahabah.

${ }^{20}$ Dedi Ismatullah, Sejarah Sosial Hukum Islam, (Bandung: Pustaka Setia, 2011 ) p. 314. 


\section{References}

Ahmad Kholik, Ahmad Kholik. Melacak Sejarah Metodologi Ijtihad. Bandung: Shahifah, 2009.

Dr.Yadi Janwari M.A, Dr. Yadi Janwari M.A. Pemikiran Ekonomi Islam dari Masa Rasulullah Hingga Masa Kontemporer. Jakarta: PT Remaja Rosdakarya., 2016.

Gül, Muammer. “İSLAM İKTİSADİ GELIŞMESININ TARIHII VE DİNI DİNAMIKLERİ.” Journal Of History School 7, no. XVII (January 1, 2014): 71-106.

'Umar, Fu'ād 'Abd Allāh. Muqaddimah fī tārīkh al-iqtiṣād al-Islāmī wa-tatawwwurih. Jiddah: al-Bank al-Islāmī lil-Tanmīyah - al-Ma‘had al-Islāmī lil-Buhūth wa-al-Tadrïb, 2003.

Ismatullah, Dedi. Sejarah Sosial Hukum Islam. Bandung: Pustaka Setia, 2011.

Karim, Adiwarman Azwar. Sejarah pemikiran ekonomi Islam. Ed. 3. Jakarta: PT RajaGrafindo Persada, 2006.

Kennedy, Hugh. The Prophet and the Age of the Caliphates: The Islamic Near East from the Sixth to the Eleventh Century. 2. ed. A history of the Near East. Harlow: Pearson Longman, 2004.

Meirison, Meirison. "Mashlahah Dan Penerapannya Dalam Siyasah as Syar'iyah." Ijtihad 32, no. 1 (April 5, 2019). Accessed December 8, 2019. http://journal.fs.uinib.ac.id/index.php/ijtihad/article/view/32.

-C-. "Riba and Justification in Practice in Scholars' Views." TRANSFORMATIF 2, no. 1 (September 20, 2018): 348.

M.Umer Chapra. Islam Dan Tantangan Ekonomi. Gema Insani Press, 2000.

Roibin. Dimensi-Dimensi Sosio-Antropologis Penetapan Hukum Islam Dalam Lintasan Sejarah. Cetakan I. Malang: UIN-Maliki Press, 2010.

Sali, Meirison Alizar. "Distinction of Justice and Fairness during Umar Bin Abdul Aziz's Reign.” AJIS: Academic Journal of Islamic Studies 4, no. 2 (December 9, 2019): 127.

Tahido Yanggo, Huzaimah. Pengantar Perbandingan Madzhab. Jakarta: Gaung Persada, 2011.

Yasid, Abu. Islam akomodatif: rekonstruksi pemahaman Islam sebagai agama universal. Cet. 1. Yogyakarta: LKiS, 2004.

مزي، يوسف بن A. J Wensinck, and, أبو داؤود سليمان بن الأشعث السجستاني،, شيحا، خليل مأمون

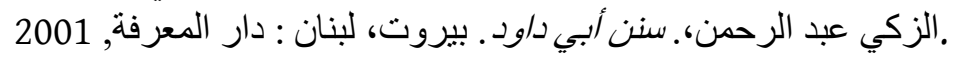

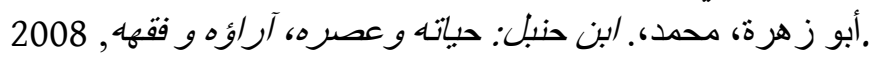

شكعة، مصطفى. الأئعة الأربعة. القاهرة; بيروت: دار الكتاب المصري ؛ دار الكتاب اللبناني،, 1991. 